\title{
DEVELOPMENT OF A MODEL OF TECHNOLOGICAL SYSTEM OF SEMI-FINISHED PRODUCTS WITH EMULSION PASTE STRUCTURE
}

\author{
Nataliya Grynchenko \\ Department of Meat Processing Technologies \\ Kharkiv State University of Food Technologies and Trade \\ 333 Klochkivska str., Kharkiv, Ukraine, 61051 \\ tatagrin1201@gmail.com \\ Daria Tyutyukova \\ Department of Meat Processing Technologies \\ Kharkiv State University of Food Technologies and Trade \\ 333 Klochkivska str., Kharkiv, Ukraine, 61051 \\ tutukova.d.o.hduht@gmail.com \\ Pavlo Pyvovarov \\ Department of Food Technology \\ Kharkiv State University of Food Technologies and Trade \\ 333 Klochkivska str., Kharkiv, Ukraine, 61051 \\ pcub@ukr.net \\ Oleksandr Nagornyi \\ Department of Food Technology \\ Kharkiv State University of Food Technologies and Trade \\ 333 Klochkivska str., Kharkiv, Ukraine, 61051 \\ niv1112@ukr.net
}

\begin{abstract}
There was realized the analysis of modern methods of modification and correction of functional-technological properties of milk proteins for increasing the efficiency of their use in the technology of emulsion products. It was demonstrated, that it is prospective to use cheese-milk mixtures, based on decalcified milk raw materials at the expanse of the increased content of soluble protein. It was proved, that the use of decalcified milk raw materials results in raising the emulsifying power of systems and also in increasing indices of aggregative and kinetic stability. There was determined the aim of the study that is in elaborating a model of the technological system of semi-products with the emulsion paste structure. There was substantiated the expedience of using methods of system analysis at modeling the technological system of semi-products with the emulsion paste structure. There was designed the model of new products using the hierarchy of subsystems by levels. The aim of functioning of each separate subsystem was determined. Connections between separate elements of the system were assessed, internal and intersystem flows between them were analyzed. The influence of separate subsystems on formation of qualitative parameters of a final product was established. There were elaborated the way of forming the assortment of culinary and confectionary products based on semi-products with the emulsion paste structure. It was demonstrated, that depending on a fat content, new semi-products may be used in technologies of cold dishes and snacks, dessert products, hot dishes of sour milk cheese, confectionary products (especially, baked and dressing semi-products) and sauce group of products. Technological advantages of using developed semi-products were presented.

Keywords: model of technological system, decalcified milk raw material, semi-product, emulsion paste structure, cheesemilk mixture, kinetic and aggregative stability.

\section{Introduction}

It is known, that for using emulsion products, stale at storage, it is necessary to introduce emulsifiers and stabilizers additionally to the recipe composition $[1,2]$. Today proteins of the animal origin, especially, milk ones are widely used as emulsifiers (stabilizers). Their use as dry soluble concentrates that, being biologically valuable components, mainly determine properties of 
a finished product and allow to improve its structure essentially [1, 3]. But at determined peculiarities of the technological process of their obtaining, there is the objective necessity to correct their functional-technological properties by chemical, biochemical, enzyme methods for realizing the technology of emulsion products [4-7].

In the last years a series of innovations that may be conventionally divided in two categories, was elaborated and implemented in the technology of such products. From one side, modern inventions are directed on giving to food products functional properties at the expanse of using probiotics, insulin-containing raw materials, grain, malty and other stuff [8]. Another category includes innovations, oriented on regulating functional-technological properties of sour-milk cheese as an initial raw material for culinary products by using stiffeners, moisture-retaining components, stabilizers of the structure and so on [9]. As to the latter ones, their use is mainly directed on eliminating obstacles and limitations that appear at producing sour-milk cheese - sineresis, unsatisfactory consistence, short storage terms and other, and doesn't provide the complex realization of technological properties of milk as a raw material.

This problem is solved by using decalcified milk raw materials, characterized by high functional properties, especially, emulsifying power that gives a possibility to provide their effective use in the technological system of semi-products with the emulsion paste structure [10, 11].

But the processes of developing new products, their implementation and presentation at the food market are chain and long. In this connection the stage of creating new products must be preceded by processes of modeling and designing a product and its quality. Such approaches allow to reveal critical weak points on numerous parameters at all production stages and also to analyze and differentially correct regimes and parameters of production processes with given consumption and hygienic characteristics.

Based on it, the aim of this study is to develop the model of the technological system of semi-products with the emulsion paste structure. Studying systems on models allows to overcome the complexity of real technological processes, to reduce incorrect solutions of real technological systems to the minimum. From the practical point of view, this principle allows to get emulsion systems at different contents of a fat component that in a certain way determines their further technological destination in the wide assortment of culinary and confectionary products.

\section{Materials and Methods}

The objects of the study were:

- skim decalcified milk;

- fatless sour milk cheese, produced of skim milk and of skim decalcified milk;

- cheese-milk mixtures, based on decalcified milk raw materials;

- semi-products, based on decalcified milk raw materials and sunflower oil.

Sour milk cheese and decalcified milk raw materials (skim milk and sour milk cheese on its base) were obtained, based on the description of the technological process, presented in [11]. Cheese-milk mixtures were obtained by mixing decalcified milk raw materials (sour milk cheese: milk) as (90:10) - (10:90).

The following research methods were used at experimental works.

The mass share of moisture in the studied systems was determined using the moisture analyzer «Kett Electric Laboratory» made by «Infrared Moisture Meter. Model F-IA» (Japan) [12].

The titrated acidity of samples of sour milk cheese and decalcified milk raw materials was determined by titration. For that, $5 \mathrm{~g}$ sample of sour milk cheese was grinded in a porcelain pestle to the homogenous consistence. Then the sample was put to a measuring glass with volume $100 \mathrm{~cm}^{3}$ and $50 \mathrm{~m}^{3}$ of distilled water with temperature $35-40{ }^{\circ} \mathrm{C}$ were added. The obtained mixture was titrated by $2 \mathrm{n}$ solution of sodium hydroxide at phenol phthalein till a faint rose coloration appears and doesn't disappear during 60 seconds. The titrated acidity of sour milk cheese was found by multiplying the volume $\left(\mathrm{cm}^{3}\right)$ of sodium hydroxide solution, spent for neutralization of acids, by coefficient 20 .

The mass share of ash in samples of sour milk cheese was determined by [13].

The moisture-retaining power of sour milk cheese was determined by the gravimetric method [12]. 
The average size of particles of sour milk cheese was determined using the microscope with a digital photo camera and personal computer with a program means ImageJ 1.47 for processing obtained photos [12].

The study of the content of total protein in sour milk cheese was realized by Kjeldahl method [14]. The degree of proteins' solubility was determined by the optic density of solutions of chosen samples on the concentration photoelectronic colorimeter CPC-2 (Russia) (Fig. 1). For preparing samples, the batch of sour milk cheese was grinded in the pestle to the homogenous mass and mixed with 0,05 $\mathrm{M}$ solution of $\mathrm{NaH}_{2} \mathrm{PO}_{4}$ with a certain $\mathrm{pH}$ value in the sample-solution ratio as 1:99.

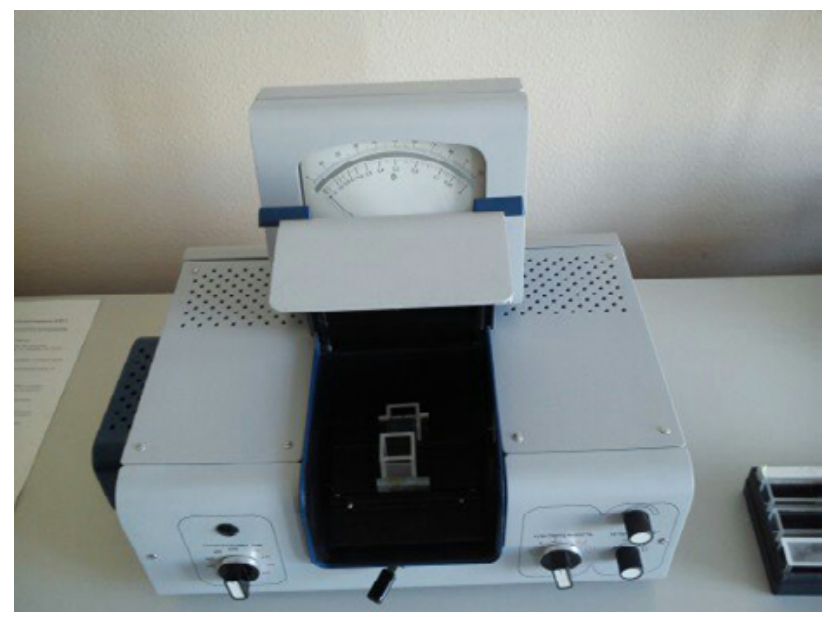

Fig. 1. Concentration photoelectronic colorimeter CPC -2

The samples were centrifuged during 5 minutes, turns number- $5000 \mathrm{~s}^{-1}$. After centrifuging $5 \mathrm{ml}$ of the supernatant liquid were put in the laboratory glass, $5 \mathrm{ml}$ of $10 \%$ solution of sodium hydroxide, 2-3 drops of $1 \%$ solution of cooper sulfate were added and mixed. Dishes with the studied sample were put in a dish-holder of the device. The wave length at measuring was $540 \mathrm{~nm}$.

The study of the emulsifying capacity of samples of cheese-milk mixtures was realized by detecting the inversion point. Emulsification was carried out on the dispergator T-18 ULTRA-TURRAX (IKA, Germany) (Fig. 2) with the speed of shaft rotation from 1500 turns/ $\min$ to 3000 turns/min.

For that the studied sample with volume $10 \mathrm{ml}$ was placed in a chemical glass with holding capacity $100 \mathrm{ml}$.

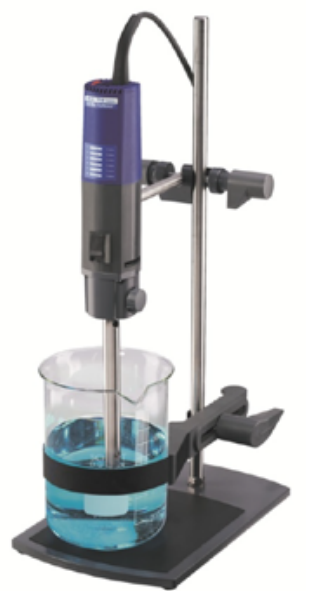

Fig. 2. Dispergator T-18 ULTRA-TURRAX

Using a measuring burette, refined deodorized sunflower oil («SUN LIGHT” LTD) was added with speed $78-80 \mathrm{drops} / \mathrm{min}$ up to phase inversion. The emulsion type was revealed by the 
dissolution method. The volume of oil, flown from the burette, corresponded to the value of phase inversion point.

The stability of emulsion was determined, fixing phase volumes, separated after centrifuging at rotor turning speed 1500 turns/min during $5 \mathrm{~min}$. Then the sample was placed on the water bath at temperature $80-85{ }^{\circ} \mathrm{C}$, kept for $3 \mathrm{~min}$ and centrifuged again during $5 \mathrm{~min}$. Stability diagrams were built based on obtained data (Fig. 3).

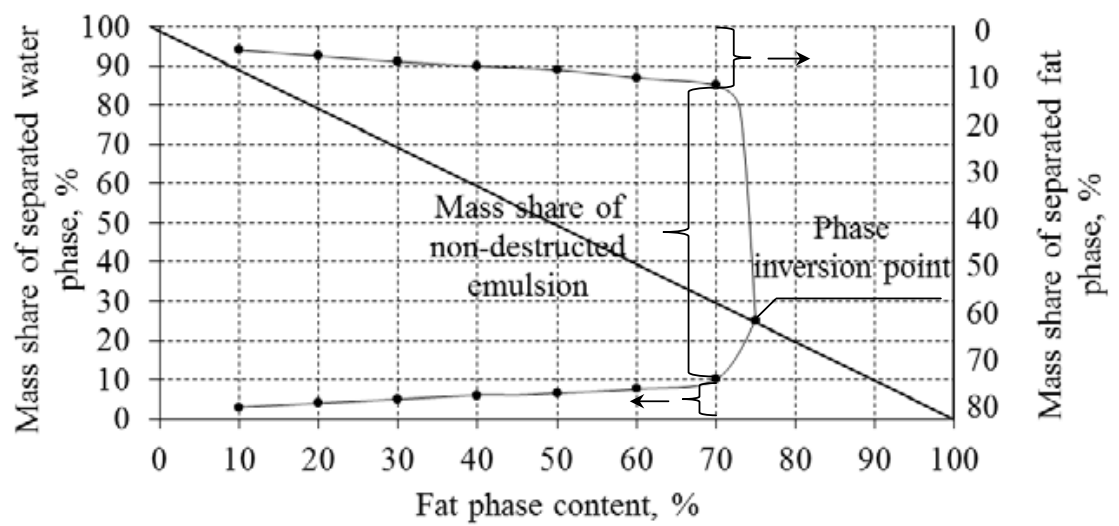

Fig. 3. General outlook of the diagram of emulsion stability

The mass share of oil volume (in \%) was fixed on the diagram on the axis of abscissas, and on the axis of ordinates, on the left and on the right - mass shares of water and fat mass, separated at centrifuging, respectively. The lines, passed through points, limit the area of separated phases (fat and volume) and area of the non-destructed emulsion.

The value of kinetic stability of emulsions was determined as a ratio of water phase volume, separated at centrifuging to the total emulsion volume by the formula:

$$
\mathrm{C}_{\mathrm{kin}}=\frac{\mathrm{V}_{\mathrm{w} . \mathrm{f}}}{\mathrm{V}_{\mathrm{em}}},
$$

where $\mathrm{C}_{\text {kin. }}$ - kinetic stability, $\% ; \mathrm{V}_{\text {w.f. }}$ - volume of separated water phase, $\mathrm{ml} ; \mathrm{V}_{\mathrm{em}}$ - emulsion volume, $\mathrm{ml}$.

The aggregative stability of the emulsion was determined as a ratio of oil volume, separated at centrifuging to the total emulsion volume by the formula:

$$
\mathrm{C}_{\mathrm{agr}}=\frac{\mathrm{V}_{\mathrm{f} . \mathrm{f}}}{\mathrm{V}_{\mathrm{em}}},
$$

where $\mathrm{C}_{\text {agr }}$ - aggregative stability, \%; $\mathrm{V}_{\text {f.f. }}$ - volume of separated fat phase, $\mathrm{ml} ; \mathrm{V}_{\mathrm{em}}$ - emulsion volume, ml.

The total stability of the emulsion was determined as a ratio of the emulsion, non-destructed at centrifuging to the total emulsion volume by the formula:

$$
\mathrm{C}_{\mathrm{tot}}=\frac{\mathrm{V}_{\mathrm{n} . \mathrm{em} .}}{\mathrm{V}_{\mathrm{em}}} \cdot 100,
$$

where $\mathrm{C}_{\text {tot }}$ - total stability of emulsion, $\% ; \mathrm{V}_{\text {n.em. }}$ - volume of non-destructed emulsion before centrifuging, $\mathrm{ml} ; \mathrm{V}_{\mathrm{em}}$ - volume of non-destructed emulsion after centrifuging, $\mathrm{ml}$.

The electronic microscopy of samples was realized using the raster electronic microscope Jeol (Japan) (Fig. 4). The main information criterion on the raster electronic microscopy is a reverse signal, received from the interaction between the flow of charged particles and the surface of the 
analyzed sample. The surface of samples was covered with the thin layer of gold under conditions of ionic spraying in the vacuum chamber (rarity degree $0,10 \mathrm{~Pa}$ ), area of sample was $1-2 \mathrm{~mm}^{2}$.

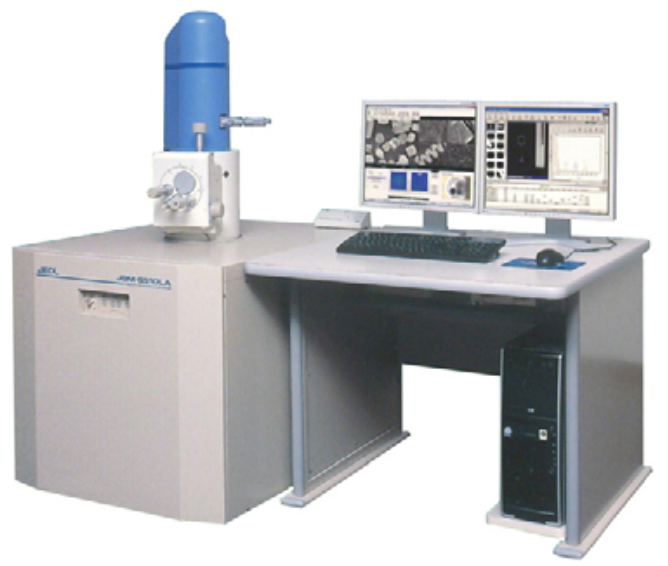

Fig. 4. Raster electronic microscope Jeol

The effective viscosity $(\eta, P a \cdot s)$ of samples was determined on the viscosimeter of constant shift strain VCS-0,2M (Special design office of the Institute of petrochemical synthesis, named after Topchiev, Russia) (Fig. 5).

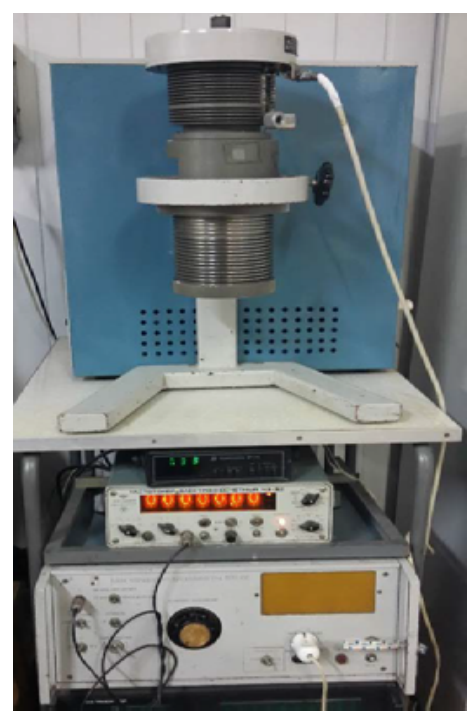

Fig. 5. Viscosimeter of constant strain VCS-0,2M

The effective viscosity was found by the formula:

$$
\eta=\mathrm{k} \cdot \mathrm{U} \cdot \mathrm{T} \cdot \mathrm{A}
$$

where $\mathrm{k}$ - constant of the measuring knot, $\mathrm{Pa} / \mathrm{V}$; $\mathrm{U}$ - strain, $\mathrm{V} ; \mathrm{T}$-turning period, s; $\mathrm{A}$ - coefficient of the measuring knot form.

The shift speed $\left(\gamma, \mathrm{s}^{-1}\right)$ was determined by the formula:

$$
\gamma=\frac{1}{\mathrm{~T} \cdot \mathrm{A}}
$$

The experimental studies were realized in the laboratory of rheological studies of Kharkiv state university of food and trade (Ukraine). 


\section{Results}

Development and implementation of technologies, directed on providing the quality and safety of food products, increasing the production efficiency at the expanse of maximal realization of functional technological properties of its components, is a sign of today. Based on it, within the offered studies there was offered to use decalcified milk raw materials in the technology of semi-products with the emulsion structure. For confirming the latter, functional-technological properties of cheese-milk mixtures, based on decalcified milk raw materials, were determined at the first stage of the studies. It was established, that at the expanse of reaching $\mathrm{pH}$ value of the system as 5,3 cheese-milk mixtures are characterized by the increased content of soluble protein. It, in its turn, provides getting stable emulsion systems with the fat content up to $68 \%$.

Generalization of analytic and experimental studies on substantiating technological parameters of producing semi-products with the emulsion paste structure for culinary and confectionary products allowed to develop the model of the technological system of their production (Fig. 6).

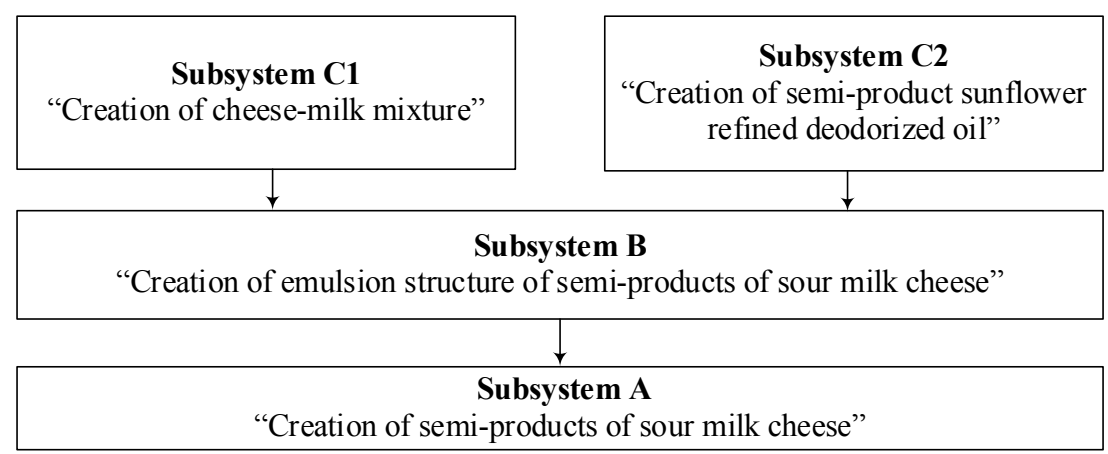

Fig. 6. Model of technological system of producing semi-products with the emulsion paste structure

The model of technological system of producing semi-products with the emulsion paste structure (Fig. 6) is presented as an integral system, within which $\mathrm{C}_{1}, \mathrm{C}_{2}, \mathrm{~B}, \mathrm{~A}$ subsystems are separated. Their functioning is directed on obtaining the final result - creation of semi-products, based on decalcified milk raw materials for culinary and confectionary products. At that it is necessary to note, that the whole system functioning is provided by the functioning of its separate components, according to the set aim. The aim of subsystems' functioning is presented in Table $\mathbf{1 .}$

Table 1

The structure of the technological system and aim of functioning of its components

\begin{tabular}{|c|c|c|}
\hline $\begin{array}{c}\text { Denotation of } \\
\text { subsystem }\end{array}$ & Name of subsystem & Aim of its functioning \\
\hline A & $\begin{array}{l}\text { creation of semi-products with } \\
\text { emulsion paste structure }\end{array}$ & $\begin{array}{l}\text { Semi-product of sour milk cheese, characterized by emulsion paste } \\
\text { structure with given properties and composition }\end{array}$ \\
\hline B & $\begin{array}{l}\text { Creation of emulsion structure of } \\
\text { semi-products of sour milk cheese }\end{array}$ & $\begin{array}{l}\text { Emulsion structure of a semi-product of sour milk cheese (at the } \\
\text { expanse of realizing technological properties of soluble proteins of } \\
\text { sour milk cheese and decalcified milk) with predictable quality and } \\
\text { safety parameters }\end{array}$ \\
\hline $\mathrm{C}_{1}$ & $\begin{array}{l}\text { Creation of cheese-milk mixture, } \\
\text { based on SDM and DSMC }\end{array}$ & $\begin{array}{l}\text { Cheese-milk mixture, based on skim decalcified milk (SDM) and } \\
\text { decalcified sour milk cheese (DSMC) as a disperse medium of the } \\
\text { emulsion structure of a semi-product of sour milk cheese }\end{array}$ \\
\hline $\mathrm{C}_{2}$ & $\begin{array}{l}\text { Creation of semi-product sunflow- } \\
\text { er refined deodorized oil }\end{array}$ & $\begin{array}{l}\text { Intermediate semi-product - deodorized refined sunflower oil as a } \\
\text { disperse phase of a semi-product with the emulsion paste structure }\end{array}$ \\
\hline
\end{tabular}

Within the subsystem $\mathrm{C}_{1}$ "Creation of cheese-milk mixture" there is received the cheesemilk mixture at the ratio of sour milk cheese : decalcified milk as $80: 20$, at which the system 
contains up to $1,2 \%$ of soluble proteins that reveals emulsifying properties. It was experimentally established, that creation of the homogenous mass of the mixture takes place at continuous mixing during (5-7) $60 \mathrm{~s}$ at the rotation speed of the working body $\mathrm{n}=1500 \mathrm{~s}^{-1}$. These conditions provide the even distribution of components, increase of $\mathrm{pH}$ of the system from 4.8 to 5.1 , that leads to the increase of the mass share of soluble proteins.

The subsystem $\mathrm{C}_{2}$ provides preparing sunflower refined deodorized oil to emulsification; especially, filtration, dosage.

The result of functioning of the subsystem B is keeping the emulsion system, within which cheese-milk mixture acts as a disperse medium, and refined deodorized sunflower oil - as a disperse phase. The emulsification process is realized in two stages: on the first one the rotation speed of the working body of the dispergator is $1500 \mathrm{~s}^{-1}$, at the second one $-3000 \mathrm{~s}^{-1}$ respectively. The necessity of conducting the emulsification process in two stages is caused by the following. At the first emulsification stage at low turns of the working body, the rough emulsion is received. That is dispersion of the fat phase takes place in the water medium. But such systems are not stable in time. That is why at the second stage there is realized emulsification at high turns that provides the thin emulsion, characterized by the even distribution of the water phase and resistance to stratification. The duration of the technological process for each stage is determined by the volume of the line, once loaded in the dispergator.

The subsystem A is realized by successive technological operations, namely cooling of the emulsion system to $10-12{ }^{\circ} \mathrm{C}$, that provides stabilization of the obtained system for the further mechanical influence during packing $(\mathrm{m}=0,5-5,0 \mathrm{~kg})$ in plastic chamber of polymer materials, marking. A semi-product of sour milk cheese is stored at temperature $0-6{ }^{\circ} \mathrm{C}$ and relative air humidity $75 \%$; storage life- no more than 10 days.

Based on the conducted studies, there were predicted the ways of using semi-products with the emulsion paste structure in enterprises of restaurant economy (Fig. 7).

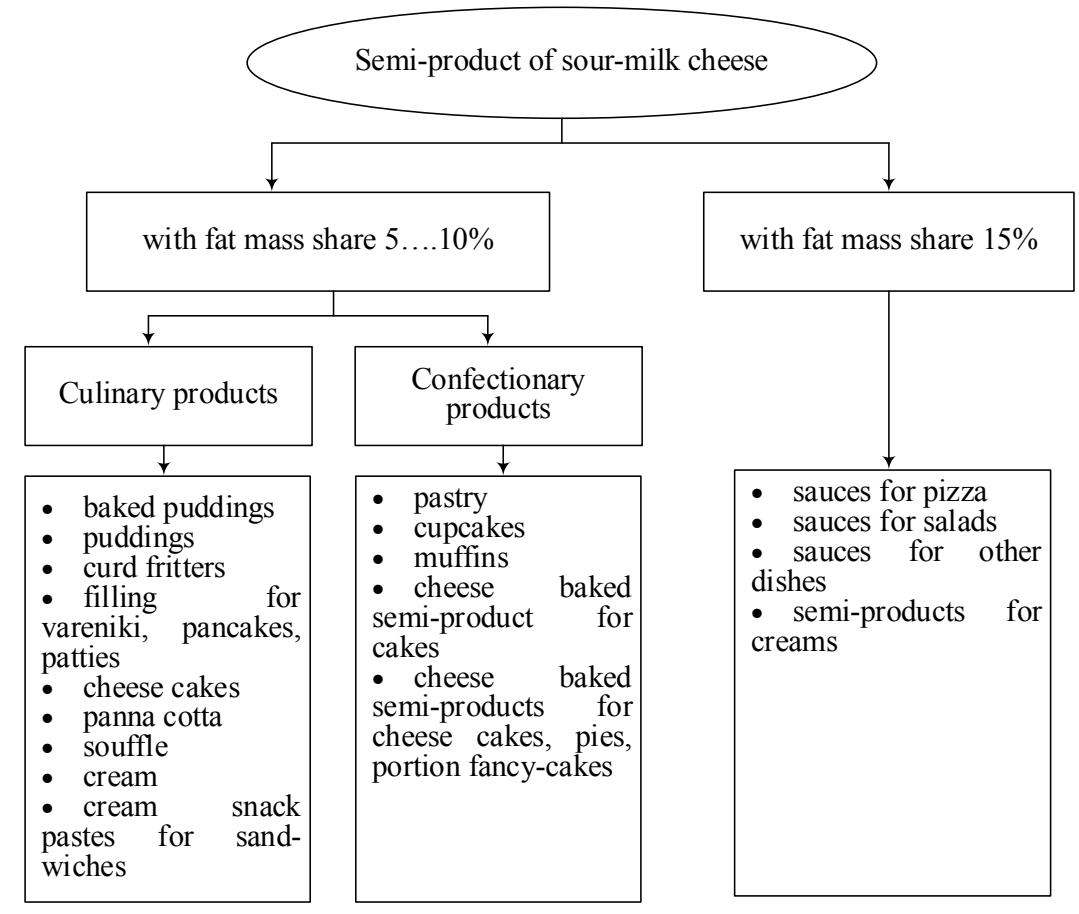

Fig. 7. Ways of using semi-products with the emulsion paste structure

This scheme demonstrates that the developed semi-products may be used in the composition of baked puddings, puddings, creams, snack pasts for sandwiches, ice-cream, cheese pastry sauces and so on. The recipe composition may be corrected by introducing additional components. 
The use of semi-products allows to facilitate the technological process of culinary and confectionary products at the expanse of absent technological operations for grinding sour milk cheese, separation of whey, emulsification and so on.

Thus, the applied aspect of realization of technological solutions is the increase of the resource potential of milk as a raw material for getting semi-products with the emulsion structure, increase of the effectiveness of the technological process, development of the wide assortment of competitive products with high consumption properties for different population layers of Ukraine.

\section{Conclusions}

Within the realized studies there was proved the expedience of using decalcified milk raw materials in the technology of semi-products with the emulsion paste structure. It was established, that the joint use of DSM and DSMC provides the increase of the content of soluble protein in the system that becomes a base for obtaining stable emulsion systems. It was demonstrated, that the change of DSM and DSMC in cheese-milk mixtures results in increasing the emulsifying power and also kinetic and aggregative stability of emulsions.

The necessity of the modeling process was proved. The model of the technological scheme of producing semi-products with the emulsion structure was developed. The main subsystems, aim of their functioning and internal connection were determined. It was demonstrated that functioning of the system in whole is provided by functioning of its separate components in the determined logic order.

Depending on the content of fat component, there were developed the ways of using semi-products with the emulsion past structure in the technology of culinary and confectionary products. Technological advantages of using the developed semi-products were presented.

\section{References}

[1] Raikos, V. (2010). Effect of heat treatment on milk protein functionality at emulsion interfaces. A review. Food Hydrocolloids, 24 (4), 259-265. doi: 10.1016/j.foodhyd.2009.10.014

[2] Singh, H., Tamehana, M., Hemar, Y., Munro, P. A. (2003). Interfacial compositions, microstuctures and properties of oil-in-water emulsions formed with mixtures of milk proteins and $\kappa$-carrageenan: 1. Sodium caseinate. Food Hydrocolloids, 17 (4), 539-548. doi: 10.1016/s0268-005x(03)00026-2

[3] Dickinson, E. (2001). Milk protein interfacial layers and the relationship to emulsion stability and rheology. Colloids and Surfaces B: Biointerfaces, 20 (3), 197-210. doi: 10.1016/s0927-7765(00)00204-6

[4] Gurova, N. V. (1997) Ekologicheski bezopasnyie belkovyie preparatyi (tehnologii ih polucheniya i primeneniya v produktah lechebno-profilakticheskogo pitaniya). Inzhenernaya ekologiya, 6, 29-34.

[5] Amine, C., Dreher, J., Helgason, T., Tadros, T. (2014). Investigation of emulsifying properties and emulsion stability of plant and milk proteins using interfacial tension and interfacial elasticity. Food Hydrocolloids, 39, 180-186. doi: 10.1016/j.foodhyd.2014.01.001

[6] Shirashoji, N., Jaeggi, J. J., Lucey, J. A. (2006). Effect of Trisodium Citrate Concentration and Cooking Time on the Physicochemical Properties of Pasteurized Process Cheese. Journal of Dairy Science, 89 (1), 15-28. doi: 10.3168/jds.s0022-0302(06)72065-3

[7] Guzman-Gonzalez, M., Morais, F., Amigo, L. (2000). Influence of skimmed milk concentrate replacement by dry dairy products in a low-fat set-type yoghurt model system. Use of caseinates, co-precipitate and blended dairy powders. Journal of the Science of Food and Agriculture, 80 (4), 433-438. doi: 10.1002/ (sici)1097-0010(200003)80:4<433::aid-jsfa545>3.3.co;2-2

[8] Granato, D., Branco, G. F., Cruz, A. G., Faria, J. de A. F., Shah, N. P. (2010). Probiotic Dairy Products as Functional Foods. Comprehensive Reviews in Food Science and Food Safety, 9 (5), 455-470. doi: 10.1111/j.1541-4337.2010.00120.x

[9] Rulliere, C., Perenes, L., Senocq, D., Dodi, A., Marchesseau, S. (2012). Heat treatment effect on polyphosphate chain length in aqueous and calcium solutions. Food Chemistry, 134 (2), 712-716. doi: 10.1016/j.foodchem.2012.02.164

[10] Plotnikova, R., Grynchenko, N., Pyvovarov, P. (2016). Study of influence of technological factors on the sorption of ionized calcium from skimmed milk by sodium alginate. Eastern-European Journal of Enterprise Technologies, 5 (11 (83)), 32-39. doi: 10.15587/1729-4061.2016.81413 
[11] Grynchenko, N., Tyutyukova, D., Pyvovarov, P. (2017). Study of quality indicators of fermented-milk cheese obtained from skimmed milk at a controlled content of calcium. Eastern-European Journal of Enterprise Technologies, 6 (11 (90)), 11-21. doi: 10.15587/1729-4061.2017.117136

[12] Grynchenko, N., Tyutyukova, D., Pyvovarov, P. (2017). Study of influence of calcium content in milk on quality indicators of cottage cheese. EUREKA: Life Sciences, 6, 22-28. doi: 10.21303/25045695.2017 .00510

[13] Lindmark-Mansson, H., Fonden, R., Pettersson, H.-E. (2003). Composition of Swedish dairy milk. International Dairy Journal, 13 (6), 409-425. doi: 10.1016/s0958-6946(03)00032-3

[14] Nelson, B. K., Barbano, D. M. (2005). A Microfiltration Process to Maximize Removal of Serum Proteins from Skim Milk Before Cheese Making. Journal of Dairy Science, 88 (5), 1891-1900. doi: 10.3168/ jds.s0022-0302(05)72865-4

\title{
INVESTIGATION OF THE ROLE OF PLASTICIZERS IN FILM-FORMING COATS FOR PROTECTING COOLED MEAT
}

\author{
Andrii Kyshenia \\ Department of meat, fish and seafood technology \\ Odessa National Academy of Food Technologies \\ 112 Kanatna str., Odessa, Ukraine, 65039 \\ andrii.kyshenia@gmail.com \\ Lydmila Vinnikova \\ Department of meat, fish and seafood technology \\ Odessa National Academy of Food Technologies \\ 112 Kanatna str., Odessa, Ukraine, 65039 \\ Tat'yana Volovik \\ Department of biochemistry, microbiology and physiology of nutrition \\ Odessa National Academy of Food Technologies \\ 112 Kanatna str., Odessa, Ukraine, 65039 \\ tavol0929@gmail.com \\ Yevhenii Kotliar \\ Department of technology of milk, fats and perfume and kosmetycheskyh funds \\ Odessa National Academy of Food Technologies \\ 112 Kanatna str., Odessa, Ukraine, 65039 \\ yevhenii11@ukr.net

\section{Kateryna Garbazhiy} \\ Department of Security, Expertise and Commodity Research \\ Odessa National Academy of Food Technologies \\ 112 Kanatna str., Odessa, Ukraine, 65039 \\ garbazhiykat@gmail.com
}

\footnotetext{
Abstract

As a result of theoretical studies on problems of protection and prolongation of storage terms of meat, it was revealed, that one of promising directions is to use protecting coats, based on natural biopolymers.

The topicality of this study is in studying film-forming coats, based on natural polysaccharides, because they have high mechanical indices, absence of a smell, taste and are subjected to biological destruction. For regulating mechanical properties, the
} 